\section{Demand Relations of Fresh Sweetpotato in the St. Louis and Chicago Markets}

\author{
Wesseh J. Wollo ${ }^{1}$ and Rufus Jones ${ }^{2}$ \\ Cooperative Research, Lincoln University, Jefferson City, MO 65102-0029
}

Additional index words. regression analysis, price flexibility, income flexibility, Ipomoea batatas

Abstract. The impacts of unloaded quantity, disposable personal income, retail price index of fresh potatoes (Solanum tuberosum L.), and seasonal monthly variables on sweetpotato [Ipomoea batatas (L.) Lam.] price in the St. Louis and Chicago terminal markets were estimated using a regression analysis technique. These markets can absorb a modest increase in sweetpotato quantity without a decrease in wholesale price, but a significant increase in quantity would decrease wholesale price. Sweetpotato price is higher during October, November, and December than in September; therefore, producers must give attention to marketing sweetpotatoes during these months. Also, increased shipments of sweetpotatoes to these markets should not be considered in anticipation of an increase in disposable income.

Farmers in Missouri are encouraged to produce vegetables for the fresh market as an alternative to the traditional crops. Sweetpotato is one such vegetable. Market outlets for sweetpotatoes produced in Missouri include the St. Louis and Chicago terminal markets. Almost all of the sweetpotatoes produced in Missouri are marketed from September to December (Charles M. Gore, personal communication). During this period, a market window for sweetpotato exists in the Chicago and St. Louis terminal markets (Wollo, 1995). The market window for a crop is the period during which the average real price of that crop is above the costs of production and marketing (Mook, 1985; Rahmani et al., 1990; Zwingli et al., 1987).

Aside from market window considerations, producers of sweetpotatoes for the Chicago and St. Louis markets increasingly have become interested in obtaining information on the demand relations for fresh sweetpotatoes in these markets.

Studies concerning estimates of demand relations for fresh sweetpotatoes in the United States are few and mostly not market specific. Epperson and Huang (1992) examined the potential for a marketing order involving management of intraseasonal shipments of southeastern sweetpotatoes through a comparison of prices, shipments, and producers' surplus measures for the dynamic competitive equilibria case and the actual market case. Their results suggest that marketing orders to control supply would not be beneficial, at least in the usual sense. The proper strategy, given the results of their study, would be to increase,

Received for publication 26 July 1995 . Accepted for publication 31 Dec. 1995. The cost of publishing this paper was defrayed in part by the payment of page charges. Under postal regulations, this paper therefore must be hereby marked advertisement solely to indicate this fact.

${ }^{1}$ Assistant Professor, Agricultural Economics.

${ }^{2}$ Associate Professor, Agronomy. rather than limit, shipments of quality sweetpotatoes with appropriate promotion in all seasons of the year.

Mathia (1975) estimated the quantitydemand relationship to evaluate consumer characteristics affecting sweetpotato consumption in various regions in the United States. He used national cross-sectional data to identify consumption patterns among white and nonwhite households. His results suggest that for the white household, family income, number of meals eaten at home, family size, and expenditures for white potatoes were important determinants of weekly sweetpotato consumption. The income elasticity of demand for sweetpotatoes at the mean for the white households was -0.11 . The income elasticity of demand for a product is the responsiveness of product consumption to changes in consumer income. The estimated relationship for nonwhite households was similar structurally to the white households, except the sample size was not sufficiently large to yield statistically
Table 1. Variable identification and description statistics. significant coefficients for some of the variables found important in white households. Nonetheless, price, consumer age, and number of households did show statistically significant coefficients.

Schrimper and Mathia (1975) estimated the reservation demand for on-farm use and market demand for sweetpotatoes in the United States. Their results indicated an inelastic $(-0.65)$ commercial demand and an elastic $(-1.25)$ reservation demand at the mean values. The estimated coefficients for the price elasticity of demand for potatoes were positive in both demand relations, suggesting that sweetpotato and potato are substitutes. The income elasticity coefficient was 0.21 for both demand relations. Because the SE for the income coefficient in each demand relation was large, the income elasticity coefficient was not significantly different from zero. This result is consistent with that reported in George and King (1971)

The result reported by Schrimper and Mathia (1975) also is consistent with the -0.07 income elasticity of demand reported in Raunikar et al. (1966). They conducted a consumption and expenditure analysis for fruits and vegetables in Atlanta and reported an income elasticity coefficient that was not significantly different from zero.

The results of these studies suggest that sweetpotato is an inferior commodity (i.e., an increase in income would result in a decrease in the consumption of sweetpotatoes). The results also suggest that, with the exception of the elastic reservation demand reported by Schrimper and Mathia (1975), the price elasticity of demand for sweetpotatoes is inelastic.

Because of a lack of recent relevant literature, producers and distributors of sweetpotatoes must rely on old research data when planning for production and distribution. Thus, our purpose was to analyze the current demand relations of fresh sweetpotatoes in the St. Louis and Chicago markets. Our focus is on the impacts on sweetpotato price at the wholesale level of factors, such as changing quantity, consumer income, and substitutes in these markets.

\begin{tabular}{|c|c|c|c|c|c|}
\hline $\begin{array}{l}\text { Variable } \\
\text { identification }\end{array}$ & Description & Mean & $\mathrm{SE}$ & Min & Max \\
\hline$\overline{\mathrm{P}_{\mathrm{ijmt}}}$ & $\begin{array}{l}\text { Monthly real price of fresh sweet- } \\
\text { potatoes in } \mathrm{i}^{\text {th }} \text { market }(\mathrm{St} \text {. Louis } \\
\text { or Chicago) for product from } \mathrm{j}^{\text {th }} \\
\text { origin }(\text { North Carolina or Louisiana) } \\
(\$ / \mathrm{kg})(1982=100 \text {, Consumer } \\
\text { Price Index })\end{array}$ & 0.53 & 0.10 & 0.33 & 0.79 \\
\hline $\mathrm{Q}_{\mathrm{ijmt}}$ & $\begin{array}{l}\text { Quantity of fresh sweetpotatoes } \\
\text { unloaded in month } \mathrm{t}(\mathrm{kg})\end{array}$ & 297,460 & 286,220 & 45,400 & $1,498,200$ \\
\hline Pindex $_{\mathrm{mt}}$ & $\begin{array}{l}\text { Monthly fresh potatoes retail price } \\
\text { index }(1982 \text { to } 1984=100)\end{array}$ & 125 & 17 & 101 & 153 \\
\hline $\mathrm{I}_{\mathrm{mt}}$ & $\begin{array}{l}\text { Monthly real per-capita disposable } \\
\text { income }(1982=100, \text { Wholesale } \\
\text { Price Index })\end{array}$ & 999 & 72 & 915 & 1,116 \\
\hline $\mathrm{S}_{\mathrm{m}}$ & $\begin{array}{l}0-1 \text { monthly seasonal variables: } \\
\mathrm{S}_{1}=\text { September (base), } \mathrm{S}_{2}= \\
\text { October, } \mathrm{S}_{3}=\text { November, and } \\
\mathrm{S}_{4}=\text { December }\end{array}$ & & & & \\
\hline $\mathrm{T}_{\mathrm{i}}$ & $\begin{array}{l}0-1 \text { variable, terminal market } T_{1}= \\
\text { Chicago (base) and } T_{2}=\text { St. Louis }\end{array}$ & & & & \\
\hline
\end{tabular}




\section{Materials and Methods}

We used the price-dependent approach to analyze the demand relations for sweetpotatoes; this approach is consistent with the premise that quantity supplied and subsequently demanded is predetermined (Fox, 1958). We also used this approach because it is easier to obtain information on flexibility coefficients. The general form of the model is specified as

$P=f\left(Q, I, Q_{s}, D\right)$

where $\mathrm{P}=$ price of the commodity, $\mathrm{Q}=$ quantity of the commodity, I = disposable income, $\mathrm{Q}_{\mathrm{s}}=$ the quantity of a substitute commodity, and $\mathrm{D}=$ a vector of dummy variables. The specific model consistent with Eq. [1] was

$$
\begin{aligned}
\ln \mathrm{P}_{\mathrm{ijmt}}= & \mathrm{B}_{\mathrm{o}}+\mathrm{B}_{1} \ln \mathrm{Q}_{\mathrm{ijmt}}+\mathrm{B}_{2} \mathrm{I}_{\mathrm{mt}}+ \\
& \mathrm{B}_{3} \ln \operatorname{Pindex}_{\mathrm{mt}}+\mathrm{B}_{4} \mathrm{~T}_{\mathrm{i}}+ \\
& \mathrm{B}_{5} \mathrm{~S}_{\mathrm{m}}+\mathrm{U}_{\mathrm{ijmt}}
\end{aligned}
$$

The form of the relationship is expressed in natural logarithm, where $\mathrm{P}_{\mathrm{ijmt}}=$ real wholesale price of fresh sweetpotatoes expressed in dollars per kilogram [1982 $=100$, Wholesale Price Index (WPI)], subscript $\mathrm{i}=$ the terminal market, $\mathrm{j}=$ the producing region, $\mathrm{m}=$ the marketing month, and $\mathrm{t}=$ the marketing year. $\mathrm{Q}_{\mathrm{ijmt}}=$ quantity (in kilograms) unloaded in the $\mathrm{i}^{\text {th }}$ terminal market from the $\mathrm{j}^{\text {th }}$ producing region during month $\mathrm{m}$ in year $\mathrm{t}, \mathrm{I}_{\mathrm{mt}}=$ real per capita income in month $\mathrm{m}$ of year $\mathrm{t}[1982=$ 100, Consumer Price Index (CPI)], and Pindex $_{\mathrm{mt}}=$ the retail price index of potatoes in month $m$ of year $t(1982-84=100)$. In a pricedependent model, quantity, rather than the price of a substitute commodity, is usually included as an explanatory or dependent variable. However, when quantity of a substitute commodity is not available, retail price index of the substitute commodity may be used (Tomek and Robinson, 1985). $\mathrm{S}_{\mathrm{m}}$ is a $0-1$ variable representing the $\mathrm{m}^{\text {th }}$ month $(\mathrm{m}=1,2$, 3, or 4: September, October, November, or December, respectively). The monthly seasonal variables were included since the level of consumption differs for each month. Because of this variability in consumption, the level of prices are expected to differ for each month. $\mathrm{T}_{\mathrm{i}}=$ a $0-1$ variable representing the $\mathrm{i}^{\text {th }}$ terminal market ( $i=1$ or 2: Chicago or St. Louis, respectively), and $\mathrm{U}_{\mathrm{ijmt}}=$ the disturbance term.

The coefficients to be estimated are $\mathrm{B}_{0}, \mathrm{~B}_{1}$, $\mathrm{B}_{2}, \mathrm{~B}_{3}, \mathrm{~B}_{4}$, and $\mathrm{B}_{5}$. Economic theory postulates that the signs of $\mathrm{B}_{1}<0$ (indicating that price and quantity are inversely related), $\mathrm{B}_{2}>0$ if sweetpotato is a normal product (indicating that consumers buy more sweetpotato at higher incomes) or $\mathrm{B}_{2}<0$ if sweetpotato is an inferior product (indicating that consumers buy less sweetpotato at higher incomes), and $\mathrm{B}_{3}>0$ if fresh sweetpotato and fresh potato are substitutes and $\mathrm{B}_{3}<0$ if they are complements. Economic theory postulates no signs for $\mathrm{B}_{0}$, $\mathrm{B}_{4}$, or $\mathrm{B}_{5}$. The signs associated with these coefficients may be either negative or positive. A probability of 0.05 was used to evaluate the significance of the estimated coefficients.

Table 1 provides a description of the variables. Weekly sweetpotato price data were obtained from the Chicago Fresh Fruit and Vegetable Wholesale Market Prices and the St. Louis Fresh Fruit and Vegetable Wholesale Market Prices publications for 1986 through 1991 (U.S. Dept. of Agriculture, 1986a, 1986b, 1987a, 1987b, 1988a, 1988b, 1989a, 1989b, 1990a, 1990b, 1991a, 1991b). These publications also contained monthly quantity data from each producing region that are unloaded in each terminal market. The weekly prices were aggregated into average monthly prices to correspond with the monthly unloaded quantity data in each terminal market. Income data for Missouri and Illinois were obtained from the Survey of Current Business for 1986 through 1991 (U.S. Dept. of Commerce, 1986, 1987, 1988, 1989, 1990, 1991) and were used to avoid relating a price series for a product as specific as sweetpotato to an overall measure of income, since doing so might have created a specification problem. The data set for markets was pooled to allow for more degrees of freedom in statistical estimation since this approach provides more efficient results than estimating separately by market. Also, the data set was pooled based on the hypothesis that the level of prices in each market differs, but the marginal effects of quantity, income, and substitutes are the same. This hypothesis was not rejected based on the Chow test (Doran, 1989).

\section{Results}

The model was expressed in natural log form, so the flexibility coefficients were obtained indirectly. The estimated regression model (Table 2) has an adjusted $R^{2}$ of 0.65 and a DurbinWatson coefficient of 1.87 after correction was made for the presence of autocorrelation using the Cochran-Orcutt method (SHAZAM, the econometrics computer program; McGraw Hill, 1993). The intercept terms for both markets were significant (Table 2), which means that the prices in these markets differ significantly. The estimate of the quantity coefficient was statistically significant, and the sign was consistent with the theory (Table 2 ). The price flexibility coefficient at the mean was -0.04 . Thus, at the mean, a $1 \%$ increase in quantity unloaded would decrease the real wholesale price by $0.04 \%$, which suggests an inflexible price.

The estimate of the income coefficient was statistically significant (Table 2). The income flexibility at the mean was -12.25 , suggesting that for each $1 \%$ increase in per-capita income, sweetpotato price would decrease by $12.25 \%$. The negative income flexibility coefficient clearly suggests that sweetpotato is an inferior product. This conclusion is consistent with those reached by Mathia (1975), George and King (1971), and Rauniker et al. (1966); but inconsistent with the conclusion reached by Schrimper and Mathia (1975).

The coefficient for the retail price index of potatoes was significant (Table 2). A $1 \%$ change in the fresh potato retail price index yields a downward change of $2.53 \%$ in the
Table 2. Estimated natural log regression coefficients for variables included in the model.

\begin{tabular}{lrr}
\hline \hline Variable & Coefficient & \multicolumn{1}{c}{$t$ ratio } \\
\hline $\mathrm{B}_{0}$ (intercept for Chicago) & 71.26 & $8.05^{* *}$ \\
$\mathrm{Q}_{\mathrm{ijmt}}$ (quantity) & -0.04 & $-1.76^{* *}$ \\
$\mathrm{I}_{\mathrm{mt}}$ (per-capita income) & -12.25 & $-8.37^{* *}$ \\
Pindex $_{\mathrm{mt}}$ & 2.53 & $8.52^{* *}$ \\
$\mathrm{~S}_{2}$ (October) & 0.07 & $2.28^{* *}$ \\
$\mathrm{~S}_{3}$ (November) & 0.20 & $4.88^{* *}$ \\
$\mathrm{~S}_{4}$ (December) & 0.23 & $7.25^{* *}$ \\
$\mathrm{~T}_{2}$ (intercept for St. Louis) & 1.69 & $8.37^{* *}$ \\
$\mathrm{~N}$ & 96 & \\
\hline
\end{tabular}

${ }^{\mathrm{z}}$ Same as $\mathrm{T}_{1}$ in Table 1.

${ }^{* *}$ Significant at $P \leq 0.05$.

wholesale price of sweetpotatoes. Thus, sweetpotatoes and potatoes are strong substitutes, which is consistent with the results of Schrimper and Mathia (1975).

The coefficients of the monthly seasonal variables were all significant (Table 2). These coefficients indicate an increase in the average price during October, November, and December in relation to September in these markets. For example, on average, the price per kilogram of sweetpotatoes in these markets would increase by $\$ 0.07, \$ 0.20$, and $\$ 0.23 / \mathrm{kg}$ in October, November, and December, respectively. These increases probably reflect a strong demand for sweetpotatoes in anticipation of the holidays: Thanksgiving, Christmas, and Hanukkah.

\section{Discussion}

Based on our results, quantity of sweetpotatoes unloaded appears to have an impact on sweetpotato price in Chicago and St. Louis. A modest increase in sweetpotatoes unloaded should have little effect on prices in these markets, but any significant increase would depress the price. The low price flexibility coefficient suggests that there is substitution between sweetpotatoes and other produce items in these markets. The coefficient for the retail price index of fresh potatoes was significant (Table 2), indicating that sweetpotato price is responsive to changes in the retail price index of potatoes.

The per-capita income variable was significant, suggesting that changes in sweetpotato price in these markets are responsive to changes in income. However, since sweetpotato is an inferior produce, an increase in the quantity of sweetpotatoes shipped should not be considered in these markets in anticipation of an increase in disposable income.

Since the coefficients of the monthly seasonal variables for October, November, and December were significant, producers must pay attention to market timing. They should focus on selling sweetpotatoes in these months in the Chicago and St. Louis markets, especially in November and December.

\section{Literature Cited}

Doran, H.E. 1989. Applied regression analysis in econometrics. Marcek Dekker, New York.

Epperson, J.E. and W.T. Huang. 1992. The potential 
for intra-seasonal market flow management of southeastern sweet potatoes. J. Food Distrib. Res. June:1-8.

Fox, K. 1958. Econometrics analyses for public policy. Iowa Univ. Press, Ames.

George, P.S. and G.A. King. 1971. Consumer demand for food commodities in the United States with projections for 1980. Giannini Foundation Monogr. 26. Calif. Agr. Expt. Sta., Univ. of California, Davis

Mathia, G.A. 1975. An economic evaluation of consumer characteristics affecting sweetpotato consumption. J. Amer. Soc. Hort. Sci. 100:529531.

McGraw Hill. 1993. SHAZAM, The econometrics computer program. McGraw Hill, New York.

Mook, R.G. 1985. Applications of market analysis: An example, p. 82-93. Proc. Analyzing Potential Alternative Fruit and Veg. Crop Production Seminar, New Orleans, 4 Nov. 1985.

Rahmani, M., T.G. Taylor, and D. Mulkey. 1990. An application of market window analysis: The case of vegetables grown on reclaimed phosphatic clay in Florida. Agribusiness 6(3):255267.

Raunikar, R., J.C. Purcell, and J.C. Elrod. 1966. Consumption and expenditure analysis for fruits and vegetables in Atlanta, Georgia. Georgia Agr. Expt. Sta. Tech. Bul., N.S. 53, June.

Schrimper, R.A. and G.A. Mathia. 1975. Reservation and market demands for sweetpotatoes at the farm level. Amer. J. Agr. Econ. 57:119-121.

Tomek, W.G. and K. L. Robinson. 1985. Agricultural product prices. Cornell Univ. Press, Ithaca, N.Y.

U.S. Department of Agriculture. 1986a. Chicago fresh fruit and vegetable wholesale market prices 1986. U.S. Dept. of Agr., Agr. Mktg. Serv., Fruit and Veg. Div., Market News Branch.

U.S. Department of Agriculture. 1986b. St. Louis fresh fruit and vegetable wholesale market prices 1986. U.S. Dept. of Agr., Agr. Mktg. Serv., Fruit and Veg. Div., Market News Branch.

U.S. Department of Agriculture. 1987a. Chicago fresh fruit and vegetable wholesale market prices 1987. U.S. Dept. of Agr., Agr. Mktg. Serv., Fruit and Veg. Div., Market News Branch.

U.S. Department of Agriculture. 1987b. St. Louis fresh fruit and vegetable wholesale market prices 1987. U.S. Dept. of Agr., Agr. Mktg. Serv., Fruit and Veg. Div., Market News Branch.

U.S. Department of Agriculture. 1988a. Chicago fresh fruit and vegetable wholesale market prices 1988. U.S. Dept. of Agr., Agr. Mktg. Serv., Fruit and Veg. Div., Market News Branch.

U.S. Department of Agriculture. 1988b. St. Louis fresh fruit and vegetable wholesale market prices 1988. U.S. Dept. of Agr., Agr. Mktg. Serv., Fruit and Veg. Div., Market News Branch.

U.S. Department of Agriculture. 1989a. Chicago fresh fruit and vegetable wholesale market prices 1989. U.S. Dept. of Agr., Agr. Mktg. Serv., Fruit and Veg. Div., Market News Branch.

U.S. Department of Agriculture. 1989b. St. Louis fresh fruit and vegetable wholesale market prices 1989. U.S. Dept. of Agr., Agr. Mktg. Serv., Fruit and Veg. Div., Market News Branch.

U.S. Department of Agriculture. 1990a. Chicago fresh fruit and vegetable wholesale market prices 1990. U.S. Dept. of Agr., Agr. Mktg. Serv., Fruit and Veg. Div., Market News Branch.

U.S. Department of Agriculture. 1990b. St. Louis fresh fruit and vegetable wholesale market prices 1990. U.S. Dept. of Agr., Agr. Mktg. Serv., Fruit and Veg. Div., Market News Branch.

U.S. Department of Agriculture. 1991a. Chicago fresh fruit and vegetable wholesale market prices 1991. U.S. Dept. of Agr., Agr. Mktg. Serv., Fruit and Veg. Div., Market News Branch.

U.S. Department of Agriculture. 1991b. St. Louis fresh fruit and vegetable wholesale market prices 1991. U.S. Dept. of Agr., Agr. Mktg. Serv., Fruit and Veg. Div., Market News Branch.

U.S. Department of Commerce. 1986. Survey of current business 1986. U.S. Dept. of Commerce, Econ. and Stat. Admin., Bureau Econ. Anal., Washington, D.C.

U.S. Department of Commerce. 1987. Survey of current business 1987. U.S. Dept. of Commerce, Econ. and Stat. Admin., Bureau Econ. Anal., Washington, D.C.

U.S. Department of Commerce. 1988. Survey of current business 1988. U.S. Dept. of Commerce, Econ. and Stat. Admin., Bureau Econ. Anal., Washington, D.C.

U.S. Department of Commerce. 1989. Survey of current business 1989. U.S. Dept. of Commerce, Econ. and Stat. Admin., Bureau Econ. Anal., Washington, D.C.

U.S. Department of Commerce. 1990. Survey of current business 1990. U.S. Dept. of Commerce, Econ. and Stat. Admin., Bureau Econ. Anal., Washington, D.C.

U.S. Department of Commerce. 1991. Survey of current business 1991. U.S. Dept. of Commerce, Econ. and Stat. Admin., Bureau Econ. Anal., Washington, D.C.

Wollo, W.J. 1995. Evaluating the market potential for sweetpotato production in southeastern Missouri. HortScience 30:135-136.

Zwingli, M.E., J.L. Adrian, W.E. Hardy, and W.J. Free. 1987. Wholesale market potential for fresh vegetables grown in north Alabama. Alabama Agr. Expt. Sta. Res. Bul. 586 